\title{
Sebaceous Adenoma on the Toe of a Dog at an Animal Hospital in Thonburi Area, Bangkok Province, Thailand
}

\author{
Athip Lorsirigool ${ }^{* 1,2}$, Chaikamon Chantrarasmee ${ }^{1}$ and Atthaporn Roongsitthichai ${ }^{2}$ \\ ${ }^{1}$ TerdThai Love Pet Hospital, Thonburi area, Bangkok Province, Thailand \\ ${ }^{2}$ The Veterinary Clinic Research Unit, Faculty of Veterinary Sciences, Mahasarakham University, Thailand \\ *Corresponding author: jlorsirigool@ hotmail.com
}

Article History: $20-135 \quad$ Received: 7-Jun-20 Revised: 01-Oct-20 Accepted: 08-Oct-20
A BS TRACT
A 7-year-old dog, Shih Tzu breed, intact male, came to an animal hospital in Thonburi area, Bangkok Province, Thailand
with symptom of licking the left forefoot. Small lumps about $1 \times 1 \times 1 \mathrm{~cm}(\mathrm{w} \times 1 \times \mathrm{h})$ were found to be protruding around the
left front toe. Surgical excision to remove the mass and subsequent histological examination identified the mass as
sebaceous adenoma. After surgery and follow-up at 12 months, there were no obvious complications. Reports of this
type concerning tumors in the paws tend to be rare. Furthermore, reports of tumor findings in this area remain unclear.
Key words: Sebceous adenoma, Dog, Histological examination

Key words: Sebaceous adenoma, Dog, Histological examination

@2020 IJVS - All Rights Reserved

\section{INTRODUCTION}

The skin is the body part that covers the most areas of the body. It is the part that exposed to the external environment, including chemicals, radiation, and physical influences. Such external environmental exposure has led to reports of benign tumors or malignant skin tumors in dogs and cats (Todorova 2006; Gross et al. 2008). Incidences of skin tumors are more common in dogs than cats. However, cases of malignant tumors on the skin are more often found in cats than dogs (Goldschmidt and Shofer 1992; Gross et al. 2008; MacDonald et al. 2008). There have been previous reports of various types of skin tumors in dogs, such as epithelial tumors (basal cell tumor), tumors with adnexal differentiation (trichoblastoma, trichoepithelioma), tumors of the epidermis (papilloma, basosquamous carcinoma), apocrine gland tumors (apocrine adenoma, apocrine adenocarcinoma), melanocytes tumors (melanoma) and sebaceous gland tumors like sebaceous adenoma, sebaceous epithelioma and sebaceous carcinoma (Pakhrin et al. 2007; Šimkus et al. 2015; Machado et al. 2018).

The sebaceous gland plays a role in secreting sebum to coat the fur and skin of animals. Tumors exhibit many external features such as a dome-shape, pedunculated papule or nodule (Yoon and Park 2016). They may be found alone or spread throughout the body. Previous reports have identified tumors in dogs from the age of 4 months to 16 years. The most common locations include the head, neck, extremities, tail, anus and perianal area (Pakhrin et al. 2007).

Diagnosis of sebaceous gland tumors is based on cytology, after which tissue samples are collected for histological examination. Characterization of sebaceous adenoma, sebaceous hyperplasia, sebaceous epithelioma, and sebaceous adenocarcinoma depends on the structure, cell composition and malignancies (mitotic index and the level of cells or nuclei atypia) (Prioleau and Santa Cruz 1984; Özyiğit et al. 2005; Azevedo et al. 2009). Treatment usually involves surgical excision to remove the mass. Previous reports suggest such treatment performed well, with no recurrence (Sananmuang et al. 2016; Parmar et al. 2019).

\section{MATERIALS AND METHODS}

\section{History}

An intact 7-year-old Shih Tzu, male dog, came to an animal hospital in Thonburi area, Bangkok Province, Thailand (establishment license 01-957/2562, latitude 13.707529, and longitude 100.478054) with symptoms of licking the left forefoot. There were small lumps protruding around the toe area. Sometimes, the dog whined when licking that area. The dog's owner informed clinical staff that he could eat normally with no vomiting, had normal feces and urine, and was the sole pet in a close- housing system. The dog was vaccinated every year and taken for flea and tick prevention regularly.

Cite This Article as: Lorsirigool A, Chantrarasmee C and Roongsitthichai A, 2021. Sebaceous adenoma on the toe of a $\operatorname{dog}$ at an animal hospital in thonburi area, bangkok Province, Thailand. International Journal of Veterinary Science 10(2): 144-147. https://doi.org/10.47278/journal.ijvs/2020.013 


\section{Clinical Examination}

The $\operatorname{dog}$ had a body weight of $6.7 \mathrm{~kg}$, rectal temperature of $102.5^{\circ} \mathrm{F}$, heart rate $120 \mathrm{bpm}$, respiratory rate $33 \mathrm{bpm}$, capillary refill time less than 2 seconds. Moreover, mucous membrane was pink, both eyes, nose, and ears were normal (symmetry, no discharge, and no swelling). Musculo-skeletal system was normal (performed by palpation; observation found no swelling, no lameness, and symmetry). Digestive system assessment found dental tartar and mild gingivitis. Feces samples from thermometer showed no diarrhea or intestinal parasites. Palpation on the popliteal and submandibular lymph nodes was symmetrical, with no swelling. Genito-Urinary system, testis and penis were normal; palpate to urinary bladder showed no distension. Integumentary system evaluation found a digit mass on the left forefoot, sized about $1 \times 1 \times 1 \mathrm{~cm}(w \times 1 \times h)$. Examination of other areas found that there were masses in other areas, such as the back and abdomen, though smaller than $1 \mathrm{~cm}$. Macroscopic examination found they were irregular, pink-colored, firm, no hemorrhage or suppurative (Fig. 1). Next, a veterinarian decided to perform surgical excision to remove the mass for histological examination.

Preparing the Dog before Surgical Removal of the Mass

A veterinarian gave the dog nothing orally (NPO) for 8 hours. Blood was collected from the cephalic vein $0.5 \mathrm{ml}$ in EDTA tube and $1 \mathrm{ml}$ in heparin tube and tested by the Veterinary Clinic Research Unit, Faculty of Veterinary Sciences, Mahasarakham University. Test results are shown in Table 1; the blood results confirmed that the dog could undergo an operation.

\section{Surgical Mass Removal and Collection of Samples for Histological Examination}

Amoxicillin-clavulanate $8.75 \mathrm{mg} / \mathrm{kg}$ (SC) and tramadol hydrochloride $4 \mathrm{mg} / \mathrm{kg}$ (SC) were administered for prophylaxis. In addition, the dog was premedicated with xylazine hydrochloride $0.5 \mathrm{mg} / \mathrm{kg}$ (IM), atropine $0.04 \mathrm{mg} / \mathrm{kg}$ (IM). Induction and maintenance were performed using propofol $5 \mathrm{mg} / \mathrm{kg}$ (IV). Surgical removal of the mass was accomplished by cutting, removing and closing the skin layers with non-absorbable sutures using a simple interrupted pattern. Mass size was $1 \times 1 \times 1 \mathrm{~cm}$, which was put in $10 \%$ neutral-buffered formalin bottle (1:9) and sent to a veterinary pathologist for histological examination. Aseptic method was used throughout the entire process.

\section{Histological Findings}

The dermis was focally expanded by a highly cellular well delineated, expansile, exophytic proliferation of neoplastic epithelial cells showing sebocyte differentiation. Neoplastic cells were arranged in lobules, small islands and trabeculae separated by coarse fibro-collagenous stroma. Within the bulk of neoplastic lobules, neoplastic cells with sebocyte differentiation had abundant vacuolated cytoplasm with distinct cell borders. Nuclei were round, finely stippled to vesiculate and contained 1-2 prominent nucleoli. Along the periphery of the neoplastic lobules and trabeculae, there was a rim of basaloid reserve cells. These cells showed scant cytoplasm with indistinct cell borders and round, hyperchromatic to vesiculate nuclei containing single prominent nucleolus. For both populations,

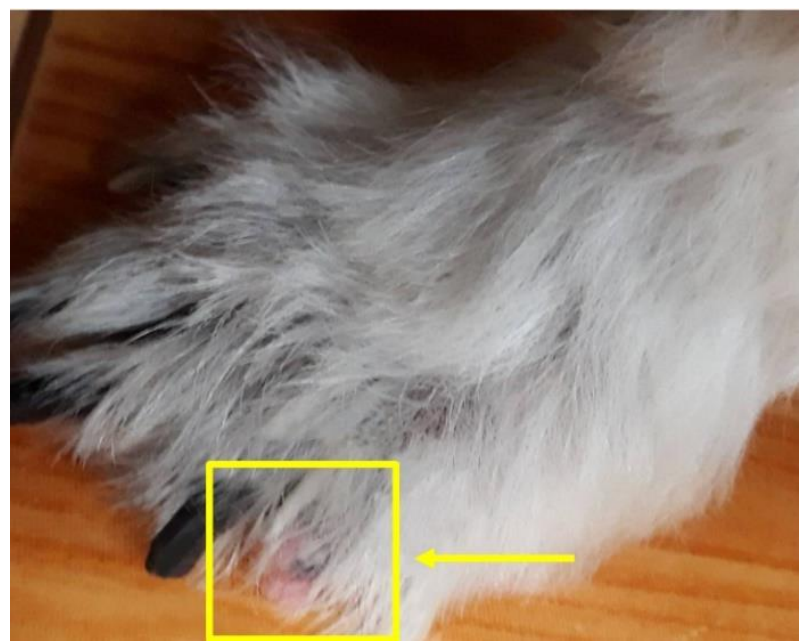

Fig. 1: Mass from the left front toe (yellow arrow).

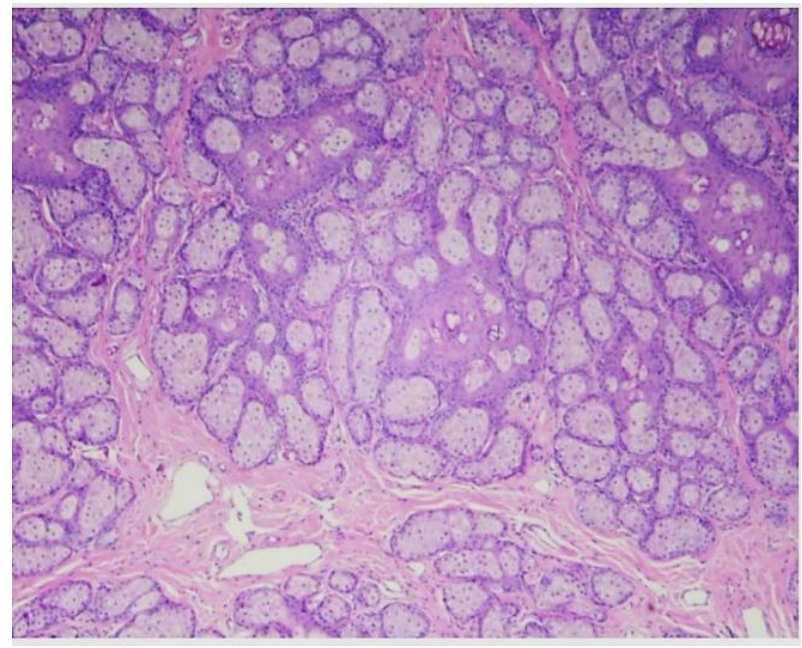

Fig. 2: A low magnification (40X) micrograph of the haired skin specimen reveals lobules of neoplastic sebocytes (sebaceous gland adenomas) (Hematoxylin and Eosin stain).

anisokaryosis was mild. Mitoses were not observed within 10 high power fields. Neoplastic lobules surrounded the central ducts lined by hyperplastic well differentiated keratinizing squamous epithelium. The epidermis was moderately to markedly hyperplastic, and had moderate laminated orthokeratotic hyperkeratosis. There were mild interstitial and perivascular infiltrates of lymphocytes and plasma cells within the superficial dermis. Neoplastic cells extended to the ventral margins of the sections examined (Fig. 2).

\section{DISCUSSION}

This study reported the sebaceous adenoma in a 7 year-old dog. As previously reported, it is commonly found in dogs with an average age of 14.13 years (Šimkus et al. 2015). While some previous reports found an average age of 10.3 years, it can be found from 4 months to 16 years of age (Pakhrin et al. 2007). For intact males, it is not possible to say that the influence of sex hormones can affect the development of this type of tumor, as it was not previously reported or collected here. However, there were some previous reports demonstrated the relationship of this neoplasm to sex hormones because high estrogen and 
Int J Vet Sci, 2021, 10(2): 144-147.

Table 1: Clinical hematology and serum chemistry of a dog

\begin{tabular}{|c|c|c|c|}
\hline \multirow[t]{2}{*}{ Parameters } & \multirow[t]{2}{*}{ Units } & \multicolumn{2}{|c|}{ Hematology and Chemistry } \\
\hline & & Results & Reference* \\
\hline White blood cell & $\times 10^{3}$ cells $/ \mu \mathrm{L}$ & 15.6 & $6.00-17.00$ \\
\hline Neutrophil & $\%$ & 67 & $58-85$ \\
\hline Band neutrophil & $\%$ & 0 & $0-3.0$ \\
\hline Lymphocyte & $\%$ & $30 \uparrow$ & $8.0-21$ \\
\hline Monocyte & $\%$ & 2 & $2.0-10.0$ \\
\hline Eosinophil & $\%$ & 1 & $0-9.0$ \\
\hline Basophil & $\%$ & 0 & $0-1.0$ \\
\hline Red blood cell & $\times 10^{6}$ cells $/ \mu \mathrm{L}$ & 7.1 & $4.80-9.30$ \\
\hline Hemoglobin & $\mathrm{g} / \mathrm{dL}$ & 16.7 & $11.90-18.90$ \\
\hline Hematocrit & $\%$ & 48.2 & $35.0-57.0$ \\
\hline Mean corpuscular volume & $\mathrm{fl}$ & 67.9 & $60.0-77.0$ \\
\hline Mean corpuscular hemoglobin & pg & 23.5 & $21.0-26.5$ \\
\hline Mean corpuscular hemoglobin concentration & $\mathrm{g} / \mathrm{dL}$ & 34.6 & $32.0-36.3$ \\
\hline Red cell distribution width-[coefficient of variation & $\%$ & 15.7 & $14.0-19.0$ \\
\hline Platelets & $\times 10^{3}$ cells $/ \mu \mathrm{L}$ & 314 & $200-500$ \\
\hline Blood urea nitrogen & $\mathrm{mg} / \mathrm{dL}$ & 13 & $8.0-28$ \\
\hline Creatinine & $\mathrm{mg} / \mathrm{dL}$ & 0.79 & $0.5-1.7$ \\
\hline Aspartate aminotransferase (Serum glutamic-oxaloacetic transaminase) & $\mathrm{U} / \mathrm{L}$ & $58 \uparrow$ & $5-55.0$ \\
\hline Alanine transaminase (Serum glutamate-pyruvate transaminase) & $\mathrm{U} / \mathrm{L}$ & 27 & $10-108$ \\
\hline Alkaline phosphatase & $\mathrm{U} / \mathrm{L}$ & 22 & $10-150$ \\
\hline
\end{tabular}

*Reference value used according to Veterinary Clinic Research Unit, Faculty of Veterinary Sciences, Mahasarakham University (Modified from March 2012: Reference ranges, 10th Ed. The Merck Veterinary Manual).

progesterone receptor expression has been reported in cases of sebaceous gland tumor than that in the normal dogs (Ginel et al. 2010). However, there are some reports showed that it was more common in males than females (Goldschmidt and Goldschmidt 2016). Breed susceptibility are still unclear. In previous reports by Machado et al. (2018) through retrospective study of 453 dogs with skin tumors, 10 were found to be Shih Tzu breed (2.21\%). In terms of changes in hematology and serum chemistry, we agree with the previous report by Sananmuang et al. (2016), which reported on dogs that have sebaceous adenoma of the external genitalia with unchanged blood values. However, this case found lymphocytosis and mild increased alanine aminotransferase (ALT), which may involve chronic inflammation, tumors, and abnormal function of the liver.

Differentiation of sebaceous adenoma from sebaceous hyperplasia, sebaceous epithelioma, sebaceous adenocarcinoma according to previous research (Azevedo et al. 2009; Amaravathi et al. 2017). The histological result of this study did not reveal mitoses and nuclei are round. This tumor was different from sebaceous hyperplasia because the tumor lacks the complete differentiation of the sebaceous lobules which can be found in sebaceous hyperplasia. In addition, it was different from sebaceous epithelioma which contains abundant vacuolated cytoplasm, with few basaloid reserve cells (Prioleau and Santa Cruz 1984).

Surgical excision in the case of sebaceous adenoma is a good option. In previous report, no recurrence was found for 12 months post-surgery (Sananmuang et al. 2016). After surgery, this case was followed up for 12 months, no complications were observed. Besides, sebaceous adenoma is rarely found in the toe area.

\section{Acknowledgements}

The authors are thankful to Dr. Tanit Kasantikul, DVM MSc., Diplo ACVP (American College of Veterinary Pathologist) confirmed histopathological results.
Furthermore, the Veterinary Clinic Research Unit, Faculty of Veterinary Sciences, Mahasarakham University, is also appreciated for assistance in this study.

\section{REFERENCES}

Amaravathi M, Murthy R, V R, Naik S, Nasreen A, Srilatha C, Sujatha K and Saibaba M, 2017. Sebaceous gland adenocarcinoma in a dog. Journal of Livestock Science 8: 18-20.

Azevedo RS, Almeida OP, Netto JNS, Miranda AMMA, Santos TCRB, Coletta RD, Lopes MA and Pires FR, 2009. Comparative clinicopathological study of intraoral sebaceous hyperplasia and sebaceous adenoma. Oral Surgery, Oral Medicine, Oral Pathology, Oral Radiology, and Endodontology 107: 100-104. https://doi.org/10.1016/ j.tripleo.2008.09.027

Ginel PJ, Lucena R, Millán Y, González-Medina S, Guil S, García-Monterde J, Monteros E, and Mulas J, 2010. Expression of oestrogen and progesterone receptors in canine sebaceous gland tumors. Veterinary Dermatology 21 : 297-302. https://doi.org/10.1111/j.1365-3164.2009.00861.x

Goldschmidt $\mathrm{MH}$ and Goldschmidt KH, 2016. Epithelial and melanocytic tumors of the skin. Tumors in domestic animals. 5th Ed, John Wiley and Sons 5: 129-131.

Goldschmidt MH and Shofer FS, 1992. Skin tumors of the dog and cat. Pergamon Press Ltd, pp: 316.

Gross TL, Ihrke PJ, Walder EJ and Affolter VK, 2008. Skin diseases of the dog and cat: clinical and histopathologic diagnosis. 2nd Ed, John Wiley and Sons, pp: 645-647.

MacDonald V, Turek M and Argyle D, 2008. Tumors of the skin and subcutis. Decision making in small animal oncology. Wiley-Blackwell pp: 129-145.

Machado G, Fontes T, Larangeira D, Estrela-Lima A, Moreira E, Ribeiro L, Pinto M and Peixoto T, 2018. Incidence of skin tumors in dogs in Salvador, Bahia state, Brazil (2007-2016). Pesquisa Veterinária Brasileira 38: 2139-2145. https://doi.org/10.1590/1678-5150-pvb-5686

Özyiğit mö, Akkoç A and Yilmaz R, 2005. Sebaceous gland adenoma in a dog. Turkish Journal of Veterinary and Animal Sciences 29: 1213-1216.

Pakhrin B, Kang MS, Bae IH, Park MS, Jee H, You MH, Kim JH, Yoon B, Choi YK and Kim DY, 2007. Retrospective study of canine cutaneous tumors in Korea. Journal of Veterinary 
Int J Vet Sci, 2021, 10(2): 144-147.

Medical Science 8: 229-236. https://doi.org/10.41420/jvs. 2007.8.3.229

Parmar JJ, Shah AI, Rao N, Godasara DJ and Patel DM, 2019. Successful surgical management of sebaceous gland tumors in dogs. The Indian Journal of Veterinary Sciences and Biotechnology 15: 79-81. https://doi.org/10.21887/ijvsbt. $\underline{15.2 .22}$

Prioleau P and Santa D, 1984. Sebaceous gland neoplasia. Journal of cutaneous pathology 11: 396-414. https://doi.org/10.1111 /j.1600-0560.1984.tb00397.x

Sananmuang $\mathrm{T}$, Jeeratanyasakul $\mathrm{P}$, Mankong $\mathrm{K}$ and Rattanapinyopituk K, 2016. Canine sebaceous adenoma of external genitalia: Case report. Journal of Applied Animal Science 9: 51-56.

Šimkus D, Pockevičius A, Mačiulskis P, Šimkienė V and Zorgevica-Pockevič L, 2015. Pathomorphological analysis of the most common canine skin and mammary tumors. Veterinarija Ir Zootechnika 69: 63-70.

Todorova I, 2006. Prevalence and etiology of the most common malignant tumors in dogs and cats. Bulgarian Journal of Veterinary Medicine 9: 85-98.

Yoon J and Park J, 2016. Immunohistochemical characterization of sebaceous epithelioma in two dogs. Iranian Journal of Veterinary Research 17: 134. 